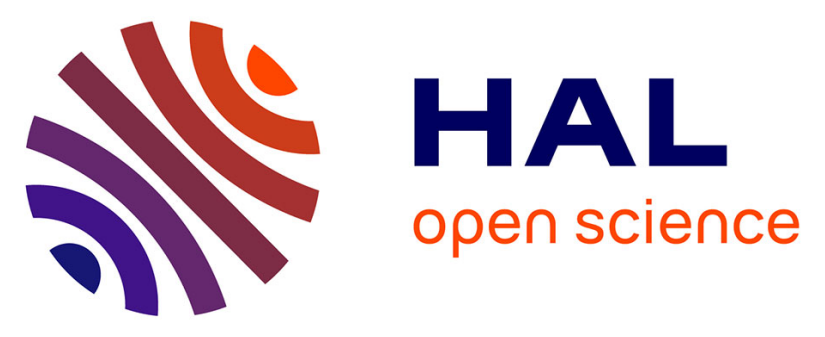

\title{
Estimation of stem and leaf dry biomass using a non-destructive method applied to African Coffea species
}

Michelle P. Okoma, Sélastique Akaffou, Philippe de Reffye, Perla Hamon, Serge Hamon, Olivier Konan, H. Kouassi, Hyacinthe Legnate, Véronique Letort, Sylvie A. Sabatier

\section{To cite this version:}

Michelle P. Okoma, Sélastique Akaffou, Philippe de Reffye, Perla Hamon, Serge Hamon, et al.. Estimation of stem and leaf dry biomass using a non-destructive method applied to African Coffea species. Agroforestry Systems, 2018, 92 (3), pp.667 - 675. 10.1007/s10457-016-0031-z . hal-01823899

\section{HAL Id: hal-01823899}

https://hal-centralesupelec.archives-ouvertes.fr/hal-01823899

Submitted on 26 Jun 2018

HAL is a multi-disciplinary open access archive for the deposit and dissemination of scientific research documents, whether they are published or not. The documents may come from teaching and research institutions in France or abroad, or from public or private research centers.
L'archive ouverte pluridisciplinaire HAL, est destinée au dépôt et à la diffusion de documents scientifiques de niveau recherche, publiés ou non, émanant des établissements d'enseignement et de recherche français ou étrangers, des laboratoires publics ou privés. 


\title{
Estimation of stem and leaf dry biomass using a non- destructive method applied to African Coffea species
}

\author{
P. Okoma - S. Akaffou - P. De Reffye - P. Hamon • \\ S. Hamon - O. Konan - K. H. Kouassi - H. Legnate • \\ V. Letort $\cdot$ S. Sabatier
}

Received: 17 April 2016/ Accepted: 20 September 2016

(C) Springer Science+Business Media Dordrecht 2016

\begin{abstract}
The coffee tree is an important economic plant for several developing countries. Stem and leaf dry biomass, which are key traits of plant production, are used in functional-structural plant models to simulate plant growth and predict yield. These values are difficult to obtain since they classically rely on time-consuming protocols and require destructive measurements. Measuring stem and leaf dimensions (length and width) to estimate them provides a nondestructive and rapid approach for use in the field. In this study we sought the best allometric relationships existing between stem and leaf dimensions and their corresponding dry mass in order to avoid destructive
\end{abstract}

P. Okoma · S. Akaffou - O. Konan · K.

H. Kouassi - S. Sabatier ( $\square)$

Université Jean Lorougnon Guédé (UJLoG),

B. P. 150, Daloa, Ivory Coast

e-mail: sylvie-annabel.sabatier@cirad.fr

P. De Reffye

CIRAD, UMR AMAP, 34398 Montpellier, France

P. Hamon · S. Hamon

UMR DIADE, IRD, B.P. 64501,

34394 Montpellier Cedex 5, France

\section{H. Legnate}

Centre National de Recherche en Agronomie, Divo, Ivory Coast

\section{Letort}

Department of Applied Mathematics, Ecole Centrale

Paris, Chatenay-Malabry, France measurements which are also time-consuming. This was investigated in three coffee species: Coffea canephora, Coffea liberica var. liberica and Coffea liberica var. dewevrei in Ivory Coast. For each species, the internodes and leaves of three axis categories (stem, branch and branchlet) comprising the main compartments were sampled. Two different equations were found to estimate the stem and leaf dry mass whatever the species and the axis categories: (1) a linear equation for the relation between the stem volume (V) and its corresponding dry mass (IWe), $\mathrm{IWe}=0.70 \times \mathrm{V}$ and (2) a power law for the relation between the leaf area [as the product of length (LL) and width (Wi)] and its dry mass (LWe), $\mathrm{LWe}=0.007(\mathrm{LL} \times \mathrm{LWi})^{1.02}$. Finally, stem and leaf dry mass could be easily obtained without destructive measurements. This method could be applied to estimate the plant total leaf area and the total stem and leaf biomass of a plant in an agroforestry system.

Keywords Coffee $\cdot$ Plant architecture - Dry mass . Leaf area $\cdot$ Allometric relationships

\section{Introduction}

The coffee tree complex comprises 124 species (Davis et al. 2011) of which two species are cultivated worldwide: Coffea arabica and C. canephora. Coffea arabica is adapted to high elevation altitude contrarily to the $C$. canephora. Only Canephora is cultivated in 
Ivory Coast and more than 380,000 families depend on coffee growing. An international collection including at least twenty African wild diploid species has been maintained in that country since 1970 for their agronomics traits and adaptive capacities to environmental conditions (Anthony 1992). This genetic resource has enabled significant progress in yields which, today, exceed 2500 tonnes/year/ha (Leroy et al. 1997; Montagnon 2000).

Coffee cultivation within agroforestry systems calls for studies to optimize growing conditions and improve production sustainability. In such studies, the measured traits are coffee tree growth, the leaf area index, and stem and leaf dry biomass which requires destructive and time-consuming measurements (Siles et al. 2010). It is thus easier and less time-consuming to measure the length and width of organs.

Much work in recent decades has reported that the architecture of coffee trees plays a key role in increasing yield potential (Cilas et al. 2006). Consequently, the number and length of branches, the number of internodes per branch and the number of flowers per node were used as important selection criteria. Thus, plant architecture analysis became a major field of investigation for understanding plant growth, branching patterns, yield, and for developing crop models (Rosati et al. 2013).

Several models have been developed to explore plant architecture and growth: ECOPHYS (Rauscher et al. 1990), EMILION (Bosc 2000), SIMWAL (Balandier et al. 2000), LIGNUM (Perttunen et al. 1998) and L-PEACH (Allen et al. 2005; Lopez et al. 2008). However, GREENLAB, a generic plant functional-structural model (Yan et al. 2004) has been found to be more appropriate for simulating plant biomass production and allocation (Wang et al. 2012). In this model, the source and sink balance controls different events in plant development, such as the number of branches or fruits (Mathieu et al. 2009). The parameters controlling plant development and growth can be computed (Wang et al. 2012; Diao et al. 2012).

We carried out a coffee tree architecture and growth analysis using the GREENLAB model. The coffee tree has relatively simple architectural development that corresponds to Roux's Model and is determined by a monopodial trunk with continuous growth during the wet season. The plagiotropic branches are inserted continuously with immediate development. The branches may bear branchlets with immediate or differed development. The leaf arrangement is opposite and decussate along the stem. Flowering is lateral and does not influence the architecture (Hallé et al. 1978). In the GREENLAB model, the development parameters were computed using data from direct observations of the plant architecture (de Reffye and $\mathrm{Hu} 2003$ ). For source-sink parameters, the input data required organ dry mass values. The organs concerned were internodes, leaves, flowers and fruits from which a plant's total aerial biomass could be computed.

As obtaining dry mass called for destructive measurements and was time-consuming for internodes and leaves, we sought allometric relationships in this study between fresh organ size and the corresponding dry mass. Such an analysis was developed by Antunes et al. (2008) to estimate leaf area from the product of leaf length by leaf width in several genotypes of $C$. arabica or of $C$. canephora. Linear models have been investigated for several species of trees (Leroy et al. 2007; Tondjo et al. 2015) and for C. canephora (Schmildt et al. 2015). Indeed, some studies focused on indirect measurements of leaf area while few studies exist on estimations of leaf dry mass from leaf dimensions. Our work proposed to determine models linking internode and leaf dimensions, i.e. internode or leaf length, internode or leaf width and their product, to leaf area and internode or leaf dry biomass for three Coffea species. Such relationships will be useful to define indirect non destructive methods for measuring these parameters in the field.

\section{Materials and methods}

Study site

The study was conducted at the experimental research station of the Centre National de Recherche Agronomique (CNRA) in Divo, $5^{\circ} 46^{\prime} 04.07^{\prime \prime} \mathrm{N}-5^{\circ} 13^{\prime}$ $22.09^{\prime \prime} \mathrm{W}$ (Ivory Coast). The altitude is low: 300 to $500 \mathrm{~m}$. The climate is tropical with an average temperature of $26-27{ }^{\circ} \mathrm{C}$ (daily amplitude of $6-7{ }^{\circ} \mathrm{C}$ ), with annual rainfall reaching $1800 \mathrm{~mm}$ and a high relative humidity of $80 \%$ on average.

\section{Studied species}

The plant material consisted of three cultivated species: C. canephora (CAN), C. liberica var. 
dewevrei (DEW) and C. liberica var. liberica (LIB). These species are adapted to low altitudes. Their origin, distribution and habitat are shown in Table 1. CAN is the only species cultivated in Ivory Coast. DEW and LIB were cultivated in Ivory Coast and Central African Republic in the 50s to 60s. Thirteen genotypes for each species, obtained from seeds, were planted in a completely randomized $3 \times 3 \mathrm{~m}$ plot design in 2010. Three 4-year-old genotypes were sampled for each species for the allometric study.

The three axis categories resulting from meristem functioning were investigated for each species: the orthotropic main stem (A1), plagiotropic branches (A2) and plagiotropic branchlets (A3). The plagiotropic branches and branchlets bore the lateral inflorescences and the fruits. Our assumption was that these axis categories have two different functions, namely space exploration or exploitation, and that these functions result in the relationship existing between organ size and mass.

Sampling and measurements

Each tree was described phytomer by phytomer and the topology was recorded following MTG formalism (Godin and Caraglio 1998). For each phytomer, the following information was recorded: internode length (IL) and internode diameter (D), leaf length (LL) and width (LWi). The internode diameter was the mean of two perpendicular diameters. The leaf length was measured from the blade tip to the blade base and leaf width corresponded to the maximum leaf width. Internodes and leaves were dried in an oven at $70{ }^{\circ} \mathrm{C}$ for $72 \mathrm{~h}$. They were weighed (We) in an anhydrous state on a balance with an accuracy of $0.01 \mathrm{~g}$. The leaf area (LA) was determined using a plug-in of Image $\mathbf{J}$ software (Toaster, Borianne and Brunel 2012). From MTG format, the biological data were extracted using
Table 2 Number of organs assessed per axis categories in the three Coffea species C. canephora (CAN), C. liberica var. dewevrei (DEW) and $C$. liberica var. liberica (LIB)

\begin{tabular}{llrrr}
\hline Axis categories & Organs & CAN & DEW & LIB \\
\hline A1 & Internodes & 113 & 74 & 74 \\
& Leaves & 32 & 9 & 7 \\
A2 & Internodes & 2090 & 498 & 515 \\
& Leaves & 738 & 167 & 53 \\
A3 & Internodes & 250 & 184 & 163 \\
& Leaves & 111 & 90 & 37 \\
\hline
\end{tabular}

the Xplo software suite from AMAPstudio (Griffon and de Coligny 2014).

The number of internodes and leaves assessed for each axis category per species is presented in Table 2 .

The internode volume (V) was approximated considering it as a cylinder: $\mathrm{V}=\mathrm{Pi} \times \mathrm{IL} \times \mathrm{D}^{\wedge} 2 / 4$.

Data analysis

We first applied descriptive statistics to calculate the mean and standard deviation for all the parameters. Then, organ size variations between genotypes and species were tested using a two-way ANOVA. A mean comparison was carried out using the Newman-Keuls test at a $5 \%$ significance level. The allometric equations were computed through regression analysis. All computations were done using Statistica Software 7.1.

\section{Results}

Tree dimensions

The tree height was $1.74 \pm 0.36 \mathrm{~m}$ for $\mathrm{CAN}$, $2.34 \pm 0.06 \mathrm{~m}$ for $\mathrm{DEW}$ and $2.39 \pm 0.34 \mathrm{~m}$ for

Table 1 Studied Coffea species. Origin, distribution and habitat from Davis et al. $(2006,2011)$

\begin{tabular}{|c|c|c|c|c|}
\hline species & $\begin{array}{l}\text { Code } \\
\text { species }\end{array}$ & Country of origin & Distribution & Habitat \\
\hline C. canephora & CAN & Cameroon & Central Africa & Humid evergreen forest \\
\hline C. liberica var. dewevrei & DEW & Central African Republic & Central Africa & $\begin{array}{l}\text { Humid evergreen forests. Seasonally } \\
\text { dry mixed evergreen forest }\end{array}$ \\
\hline C. liberica var. liberica & LIB & Ivory Coast & West Africa & Humid evergreen forest \\
\hline
\end{tabular}


Table 3 Descriptive statistics (mean (standard deviation)) of the parameter measured on the internodes according to species (CAN: Coffea canephora; DEW: C. liberica var. dewevrei;
LIB: C. liberica var. liberica) and axis categories: A1: main stem; A2: branches and A3: branchlets

\begin{tabular}{|c|c|c|c|c|c|c|c|c|c|}
\hline & \multicolumn{3}{|l|}{ CAN } & \multicolumn{3}{|l|}{ DEW } & \multicolumn{3}{|l|}{ LIB } \\
\hline & A1 & A2 & A3 & A1 & A2 & A3 & A1 & A2 & A3 \\
\hline Length (cm) & $3.33(1.38)$ & $4.70(1.73)$ & $5.10(2.38)$ & $8.70(3.83)$ & $7.05(2.75)$ & $2.80(2.60)$ & $7.02(3.24)$ & $5.63(2.67)$ & $4.85(2.42)$ \\
\hline $\operatorname{Min}-\max$ & $0.5-7.8$ & $0.1-11.3$ & $0.7-12.2$ & $2.2-19.1$ & $0.5-17.9$ & $0.7-14.1$ & $1-17.2$ & $0.3-16.4$ & $0.9-14.4$ \\
\hline Diameter $(\mathrm{cm})$ & 2.18 (1.35) & $0.47(0.16)$ & $0.30(0.11)$ & $2.12(1.20)$ & $0.67(0.26)$ & $0.44(0.13)$ & $1.91(1.04)$ & $0.58(0.21)$ & $0.45(0.14)$ \\
\hline Min-max & $0.4-6.2$ & $0.1-1$ & $0.1-0.5$ & $0.4-4.6$ & $0.2-1.7$ & $0.2-0.8$ & $0.2-4.1$ & $0.2-1.3$ & $0.2-0.8$ \\
\hline Weight (g) & $16.62(24.04)$ & $0.69(0.59)$ & $0.28(0.26)$ & $26.64(29.50)$ & $1.95(2.28)$ & $0.55(0.54)$ & $17.46(17.28)$ & $1.21(1.52)$ & $0.55(0.59)$ \\
\hline Min-max & $0.02-145.0$ & $0.01-3.9$ & $0.01-1.4$ & $0.07-118.6$ & $0.01-13.8$ & $0.01-2.9$ & $0.02-68.2$ & $0.01-11.7$ & $0.01-3.3$ \\
\hline
\end{tabular}

LIB. The basal diameter was $4.91 \pm 1.37 \mathrm{~cm}$ for CAN, $4.22 \pm 1.10 \mathrm{~cm}$ for DEW and $3.91 \pm 0.23 \mathrm{~cm}$ for LIB.

Internode volume and dry mass

For CAN, the branch internodes $(\mathrm{A} 2,4.7 \pm 1.7 \mathrm{~cm})$ were significantly $(\mathrm{p}<0.001)$ longer than those on the main stem (A1; Table 3). A large difference was observed between internode sizes along the branches, with the length ranging from 0.09 to $11.3 \mathrm{~cm}$. For DEW, unlike CAN, the mean A2 internodes were shorter than those on the main stem: $7.0 \pm 2.7$ versus $8.7 \pm 3.8 \mathrm{~cm}(\mathrm{p}<0.001)$. The internode size ranged from 0.5 to $17.9 \mathrm{~cm}$. For LIB, branch internodes were also shorter than main stem internodes, as for DEW. The means recorded were $5.6 \pm 2.7 \mathrm{~cm} \quad(0.03-$ $16.4 \mathrm{~cm}$ ) for length. The three species differed greatly for the branch internode length: DEW exhibited the largest size and CAN the smallest (Table 3). For CAN, their length along the branchlet ranged from 0.7 to $12.2 \mathrm{~cm}(5.1 \pm 2.4 \mathrm{~cm})$.

For DEW, the A3 internodes measured from 0.7 to $14.1 \mathrm{~cm}(5.8 \pm 2.6 \mathrm{~cm})$ in length. The A3 size variation in LIB was similar to that of DEW: $0.9-14.4 \mathrm{~cm}$ $(4.8 \pm 2.4 \mathrm{~cm})$ in length. The A3 for CAN were slightly longer $(p<0.05)$. Conversely, for DEW and LIB the A3 were shorter $(\mathrm{p}<0.001)$ than the A2.

A linear regression model was obtained for the internode volume and dry mass (Fig. 1). The volume was a good predictor of dry mass. The regression was significant for CAN with $\mathrm{R}^{2}=0.98,0.93$ and 0.91 for $\mathrm{A} 1, \mathrm{~A} 2$ and A3, respectively, for DEW with $\mathrm{R}^{2}=0.98,0.98$ and 0.93 for $\mathrm{A} 1, \mathrm{~A} 2$ and $\mathrm{A} 3$, respectively, and for LIB with $\mathrm{R}^{2}=0.99,0.97$ and 0.97 for $\mathrm{A} 1, \mathrm{~A} 2$ and $\mathrm{A} 3$, respectively.
Finally, the A1, A2 and A3 internode size and dry mass varied significantly within and between the studied species CAN, DEW and LIB. However, the internode volume was a good predictor of the corresponding dry mass, whatever the species. The adjusted $\mathrm{R}^{2}$ value recorded generally was over 0.90 and the equation followed a linear law: $\mathrm{Y}=0.7 \times V$.

As the linear regression coefficient was nearly 0.7 for each species, we calculated the expected dry mass from the equation: $\mathrm{Y}=0.7 \times V$ and sought a relationship between the estimated and measured dry mass. The adjusted $\mathrm{R}^{2}$ was 0.99 and the linear coefficient 1 , resulting from a perfect correlation between the two variables (Fig. 2).

Leaf dimensions and leaf area or dry mass

The descriptive statistics of the measured traits are presented in Table 4. The sample included old leaves that had reached their final dimensions as well as young leaves still in their early growth phase. Table 4 gives the means and variation (standard deviation) of the studied parameters for each axis category in the three species. The two-way ANOVA showed that the three species differed greatly for leaf size and dry mass, whatever the axis category $(p<0.001)$. LIB displayed the largest leaves followed by DEW and CAN. In addition, within each species, the leaves of the branches and branchlets did not differ for all the assessed traits $(\mathrm{p}>0.5)$ while they were significantly larger than those of the main stem, except for LIB (Table 4).

In CAN, the size of the main stem leaves varied from 2.5 to $15.9 \mathrm{~cm}(11.14 \pm 4.0 \mathrm{~cm})$ in length and from 1 to $7.6 \mathrm{~cm}(4.9 \pm 1.7 \mathrm{~cm})$ in width (Table 3). The corresponding dry mass ranged from 0.02 to $0.9 \mathrm{~g}$ 

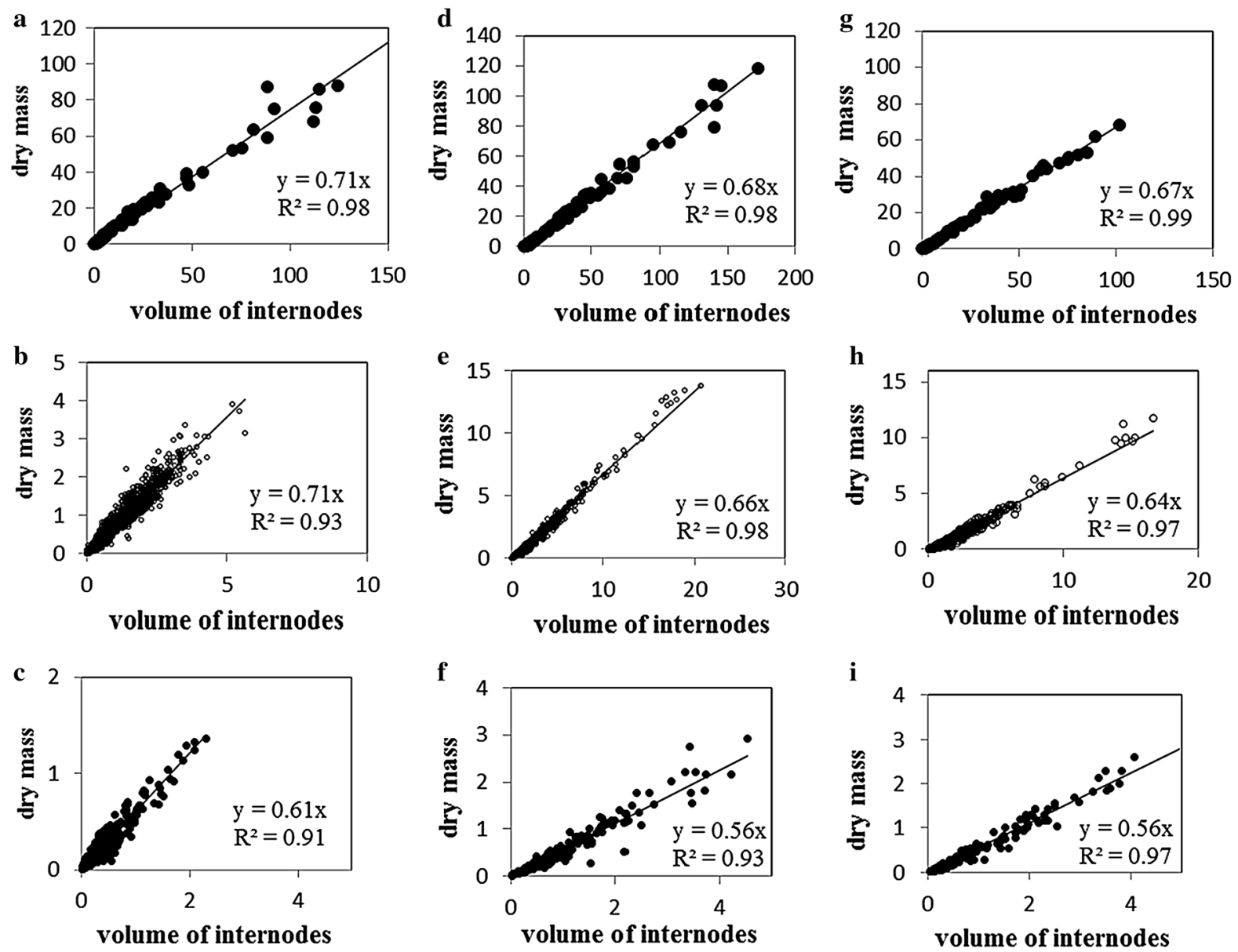

Fig. 1 Linear regression between the internode volume $\left(\mathrm{cm}^{3}\right)$ and internode dry mass ( $\mathrm{g}$ ) according to axis categories: main stem (a), branches (b) and branchlets (c) for C. canephora

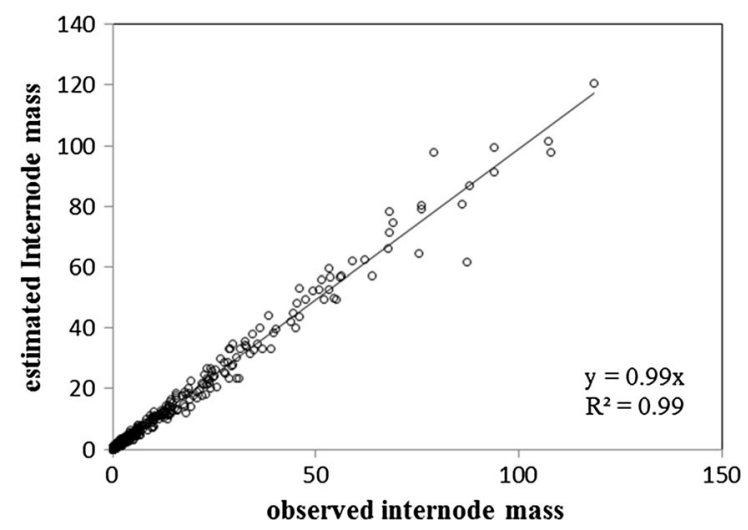

Fig. 2 Relationship between observed and estimated internode dry mass (IN mass) using the allometric relationship $\mathrm{Y}=0.7 \times V$ in Coffea canephora, $C$. liberica var. dewevrei and $C$. liberica var. liberica
(CAN); main stem (d), branches (e) and branchlets (f) $C$. liberica var. dewevrei (DEW) and main stem (g), branches (h) and branchlets (i) C. liberica var. liberica (LIB)

$(0.43 \pm 0.22 \mathrm{~g})$. On average, for $\mathrm{A} 2$ and $\mathrm{A} 3$, the leaves measured $13.9 \pm 4.6 \mathrm{~cm} \times 5.4 \pm 1.8 \mathrm{~cm}$ and $13.1 \pm$ $3.9 \mathrm{~cm} \times 4.5 \pm 1.4 \mathrm{~cm}$, respectively. The dry mass was $0.68 \pm 0.42 \mathrm{~g}$ for A2 and $0.42 \pm 0.25 \mathrm{~g}$ for A3. In DEW, the leaves of the A1 measured $16.2 \pm 4.2 \mathrm{~cm} \times$ $6.7 \pm 1.7 \mathrm{~cm}$ and weighed $0.98 \pm 0.61 \mathrm{~g}$. For the A2 and A3 axis categories, leaf sizes were $18.4 \pm$ $5.6 \mathrm{~cm} \times 8.1 \pm 2.7 \mathrm{~cm}$ for $\mathrm{A} 2$ and $16.6 \pm 4.1 \mathrm{~cm} \times$ $6.8 \pm 2.3 \mathrm{~cm}$ for A3. In LIB, the data recorded were $17.7 \pm 5.0 \mathrm{~cm} \times 8.5 \pm 3.5 \mathrm{~cm}$ with a dry mass of $1.46 \pm 0.98 \mathrm{~g}$ for A1. For A2 and A3, leaf sizes were $15.2 \pm 6.3 \mathrm{~cm} \times 6.90 \pm 3.3 \mathrm{~cm}$ and $15.5 \pm 6.0 \times$ $6.90 \pm 3.3 \mathrm{~cm}$, respectively. Their dry mass was $0.94 \pm 0.9$ and $0.84 \pm 0.7 \mathrm{~g}$, respectively. The DEW and LIB leaves were significantly larger than those of CAN. 
Table 4 Descriptive statistics (mean (standard deviation)) of the parameter measured on the leaves according to species (CAN: C. canephora; DEW: C. liberica var. dewevrei; LIB: $C$.

\begin{tabular}{|c|c|c|c|c|c|c|c|c|c|}
\hline & \multicolumn{3}{|l|}{ CAN } & \multicolumn{3}{|l|}{ DEW } & \multicolumn{3}{|l|}{ LIB } \\
\hline & A1 & $\mathrm{A} 2$ & A3 & $\mathrm{A} 1$ & $\mathrm{~A} 2$ & A3 & A1 & $\mathrm{A} 2$ & A3 \\
\hline $\begin{array}{l}\text { Length } \\
(\mathrm{cm})\end{array}$ & 11.14 (3.97) & $13.86(4.60)$ & $13.15(3.92)$ & $16.22(4.25)$ & $18.41(5.65)$ & $16.59(4.13)$ & $17.71(5.00)$ & $15.23(6.32)$ & $15.62(6.15)$ \\
\hline Min-max & $2.5-15.9$ & $2-22.8$ & $4.2-20.3$ & $11.4-24.6$ & $2.7-28.4$ & $2.3-29.1$ & $11.7-24$ & $3.4-29.8$ & $1.8-25.8$ \\
\hline $\begin{array}{l}\text { Width } \\
(\mathrm{cm})\end{array}$ & $4.91(1.66)$ & $5.40(1.84)$ & $4.46(1.44)$ & $6.70(1.73)$ & $8.16(2.75)$ & $6.78(2.34)$ & $8.48(3.54)$ & $6.90(3.29)$ & $6.86(3.30)$ \\
\hline Min-max & $1-7.6$ & $0.6-17.2$ & $1.3-7.2$ & $4.7-10$ & $1.1-14.5$ & $1-14.9$ & $4.1-13$ & $1.7-16.7$ & $0.9-13.3$ \\
\hline $\begin{array}{l}\text { Area } \\
\qquad(\mathrm{cm} 2)\end{array}$ & $42.09(22.04)$ & $58.22(33.11)$ & $43.89(23.94)$ & $75.16(41.13)$ & $114.49(59.28)$ & 83.49 (49.58) & $115.38(74.93)$ & $84.58(68.96)$ & $85.78(63.54$ \\
\hline Min-max & $2-75.6$ & $1-153.2$ & $5.3-97$ & $36.2-172.7$ & $2.5-281.9$ & $1.6-311.5$ & $35-227.2$ & $2.9-344.9$ & $1-239.8$ \\
\hline Weight (g) & $0.43(0.22)$ & $0.68(0.42)$ & $0.42(0.25)$ & $0.98(0.61)$ & $1.29(0.74)$ & $0.79(0.48)$ & $1.46(0.98)$ & $0.94(0.89)$ & $0.86(0.71)$ \\
\hline Min-max & $0.02-0.91$ & $0.01-2.1$ & $0.04-1.2$ & $0.24-2.29$ & $0.02-3.28$ & $0.01-2.72$ & $0.4-2.78$ & $0.03-4.53$ & $0.01-3.3$ \\
\hline
\end{tabular}

liberica var. liberica) and axis categories: A1: main stem; A2: branches and A3: branchlets
A linear regression model was obtained for the product LL $\times$ LWi and leaf area for each species and for each axis categories (Fig. 3). As no significant difference were found between axis categories, they were regrouped for each species. Thus linear regression was significant for CAN with $\mathrm{R}^{2}=0.99$ $(\mathrm{LA}=0.71 \times \mathrm{LL} \times \mathrm{LWi})$, for Dew with $\mathrm{R}^{2}=0.99$ $(\mathrm{LA}=0.69 \times \mathrm{LL} \times \mathrm{LWi})$ and for $\mathrm{LIB}$ with $\mathrm{R}^{2}=1$ $(\mathrm{LA}=0.69 \times \mathrm{LL} \times \mathrm{LWi})$.

The leaf mass (LWe) prediction model based on the product of LL $\times$ LWi was a power law (Fig. 4). The equations were $\mathrm{LWe}=0.007 \quad(\mathrm{LL} \times \mathrm{LWi})^{1.03}$ $\left(\mathrm{R}^{2}=0.94\right)$ for CAN, $\mathrm{LWe}=0.004(\mathrm{LL} \times \mathrm{LWi})^{1.10}$ $\left(\mathrm{R}^{2}=0.95\right)$ for $\mathrm{DEW}$ and $\mathrm{LWe}=0.005(\mathrm{LL} \times$ $L W i)^{1.05}\left(R^{2}=0.97\right)$ for LIB. No significant difference was found between species. We thus propose only one power law: $\mathrm{LWe}=0.007(\mathrm{LL} \times \mathrm{LWi})^{1.02}$ with $\mathrm{R}^{2}=0.95$.

The estimated and measured leaf dry mass values were significantly correlated, with $\mathrm{R}^{2}=0.90$ (Fig. 5).

\section{Discussion}

Estimation of stem and leaf dry biomass from internode volume and the product of leaf length by leaf width

The first objective of this work was to establish a relationship between fresh internode size (i.e. length and diameter) and dry mass. The fine investigations we carried out for the internode size indicated that the three species studied, C. canephora (CAN), C. liberica var. dewevrei (DEW) and C. liberica var. liberica (LIB), differed significantly. In addition, great variation was found within and between the axis categories $\mathrm{A} 1, \mathrm{~A} 2$ and $\mathrm{A} 3$. The $\mathrm{A} 1$ internodes were larger in diameter than the $\mathrm{A} 2$ and $\mathrm{A} 3$ internodes. They were also longer in comparison with the $\mathrm{A} 2$ and $\mathrm{A} 3$ internodes, except for CAN in which the A1 internodes were shorter than the A2 and A3 axes. Despite the differences encountered between the species and between the axis categories, a unique linear regression was found to estimate the dry mass from the internode volume. The equation parameter corresponded to the wood density, which was similar for the three species studied.

We found that a power law model described the relation between Coffea leaf mass and the product of its length by width. The same model has been found for Tectona grandis (Tondjo et al. 2015). As the measured leaves in this study were sampled at several node ranks of the leafy axis, and the leaves therefore had different ages, the observed trend might be explained by an increase in leaf thickness with leaf age (Niinemets 2001).

We thus provide a method to compute the total stem aerial biomass of coffee trees. The plant dry matter analysis enabled us to evaluate coffee tree response to the availability of water and nutrient resources and helped in the selection of genotypes with drought tolerance (Dias et al. 2007). Our results will make it 

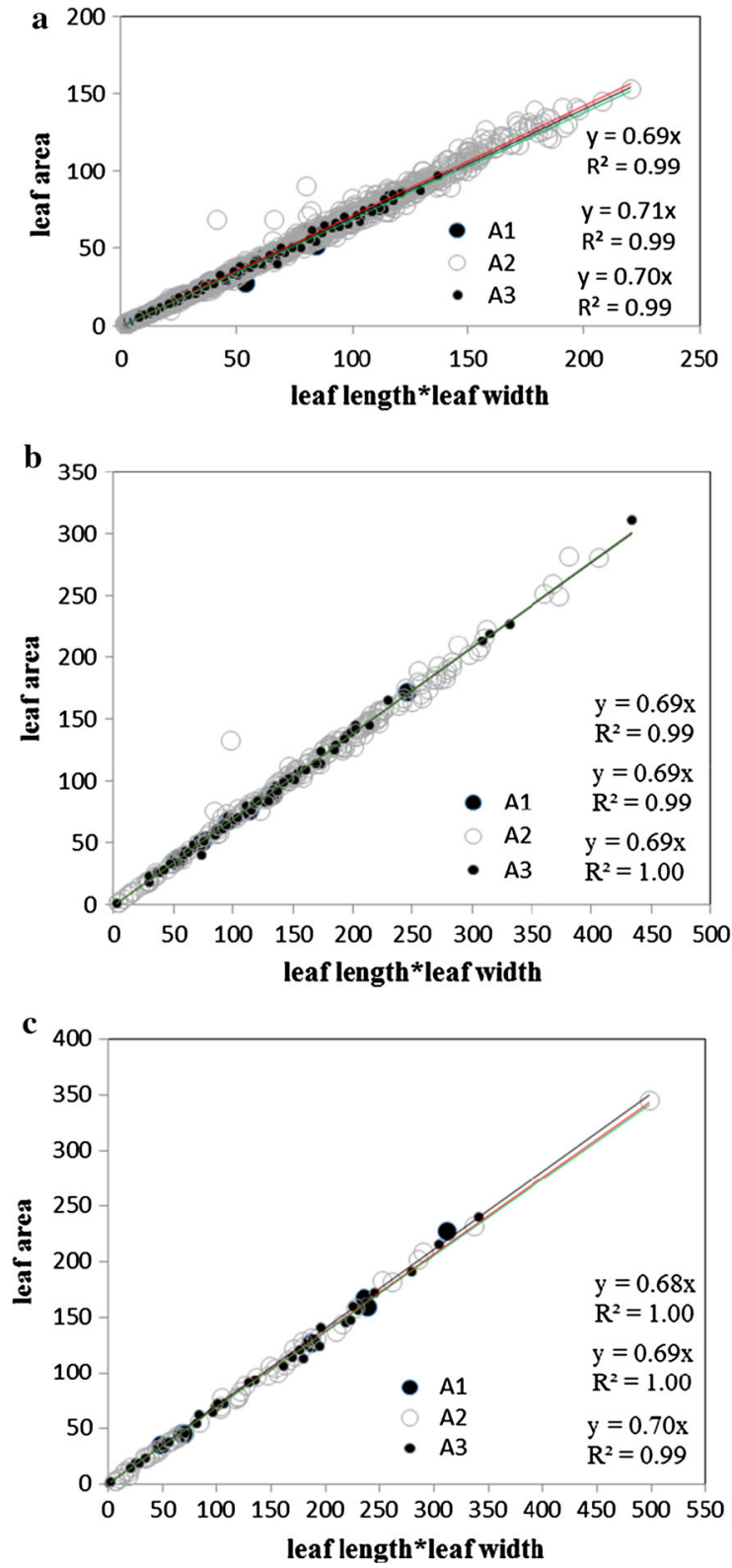

Fig. 3 Linear regression between the product of leaf length by leaf width $(\mathrm{cm})$ and leaf area $\left(\mathrm{cm}^{2}\right)$ for $C$. canephora (CAN, a), C. liberica var. deweverei (DEW, b) and C. liberica var. liberica $(\mathrm{LIB}, \mathbf{c})$ according to axis categories: main stem $(A 1)$, branches $(A 2)$ and branchlets $(A 3)$

possible to calibrate the structural-functional GreenLab model and to propose ideotypes to optimize plant yield.
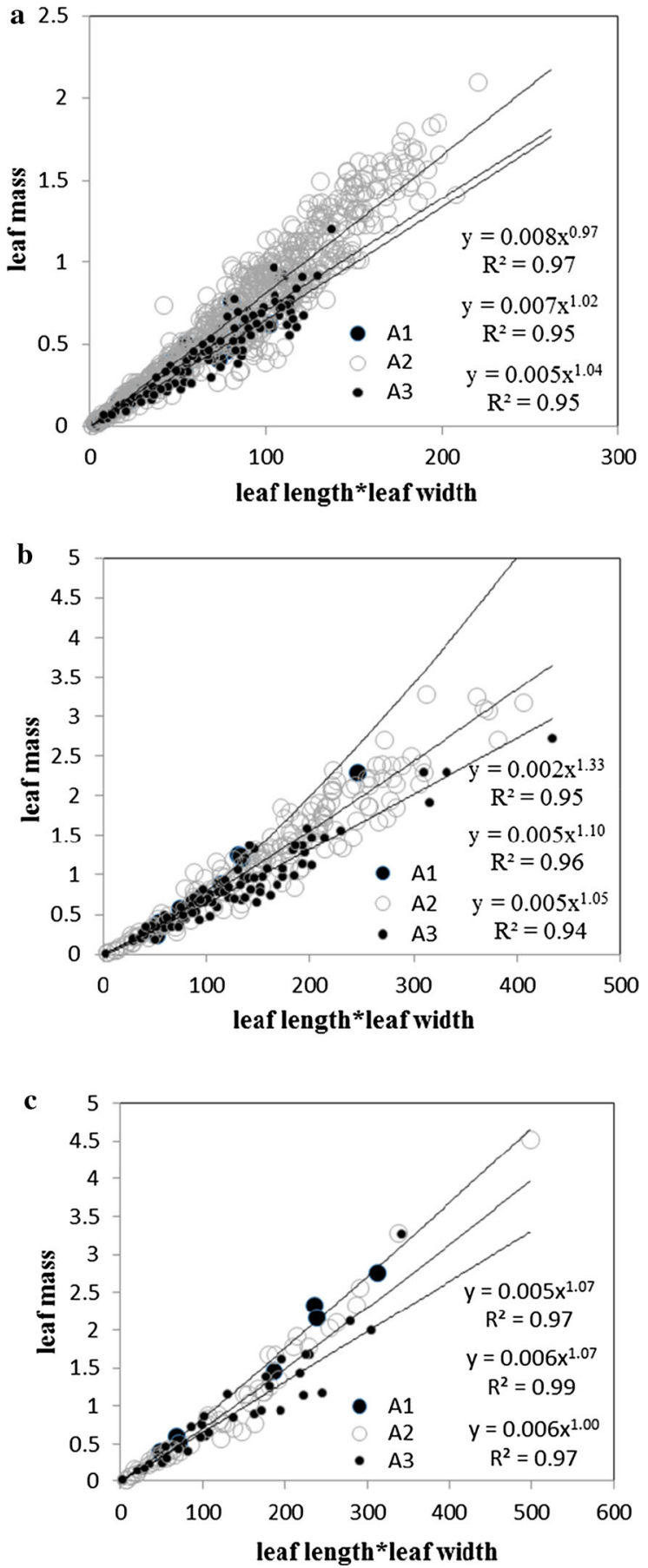

Fig. 4 Power law between the product of leaf length by leaf width $(\mathrm{cm})$ and leaf dry mass (g) for $C$. canephora (CAN, a), $C$. liberica var. deweverei (DEW, b) and C. liberica var. liberica $(\mathrm{LIB}, \mathbf{c})$ according to axis categories: main stem $(A 1)$, branches (A2) and branchlets (A3) 


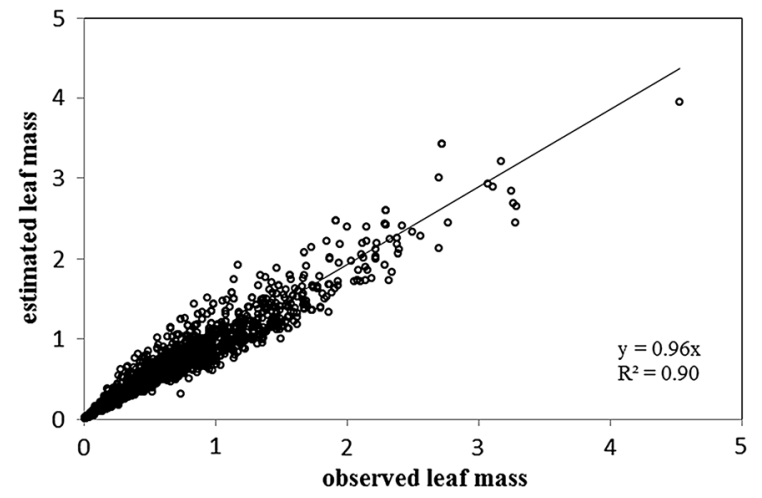

Fig. 5 Relationship between observed and estimated leaves dry mass using a power law equation $\mathrm{LWe}=0.007(\mathrm{LL} \times \mathrm{LWi})^{1.02}$ in $C$. canephora, $C$. liberica var. dewevrei and $C$. liberica var. liberica

Estimation of leaf area from the product of leaf length by leaf width

We described an estimation of leaf area from simple non-destructive measurements in three Coffea species with a linear regression including the product of leaf length by width. As in teak, this linear relation resulted from leaf expansion due to intercalary meristem activity (Bell 1991; Tondjo et al. 2015). The equations were similar between the axis categories of one species and between species. A similar equation has been found for Coffea arabica species (Siles et al. 2010). This result suggests strong genetic control of leaf shape traits such as the blade length to width ratio. Only the leaf size varied with the age and the genotype.

One of the yield components is the leaf area. In fact, there is a relationship between the leaf area supporting each fruit and bean size and quality. Coffee is grown under natural conditions in the understory, so increased knowledge of the relationship existing between the canopy architecture and light interception of the coffee tree will enable improvements to be made to farming practices in agroforestry systems (DaMatta et al. 2007).

Effect of architecture traits on leaf and stem parameters

Coffea species show strong differentiation between a strict orthotropic main stem and irreversible plagiotropic branches (Hallé et al. 1978). Our results showed a similar relation between leaf area and mass for orthotropic and plagiotropic axes. The axis categories only impacted the internode size and leaf size.

To conclude, this study proposes only one equation to estimate stem dry mass from the internode volume. The linear relation for estimating the leaf area from the product of length by width was also the same for all species whatever the axis category. Leaf dry mass was estimated from a power law that was similar between species and axis categories. In this way, organ dry mass can be estimated by easy measurements taken directly on the tree.

Acknowledgments This work was supported by the "Jeune Equipe Associée à l'Institut de Recherche pour le Développement (JEAI) Program", project ModelCaf, by the plant Diversity Adaptation and Development, joint research unit (UMR DIADE) and by the Botany and Computational Plant Architecture, joint research unit (UMR AMAP). We thank the CNRA station at Divo for their technical support and facilities for the field trials.

\section{References}

Allen MT, Prusinkiewicz P, DeJong TM (2005) Using L-systems for modeling source-sink interactions, architecture and physiology of growing trees: the LPEACH model. New Phytol 166:869-880

Anthony F (1992) Les ressources génétiques des caféiers: collecte, gestion d'un conservatoire et évaluation de la diversité génétique. Collection Travaux et documents microfichés de l'IRD, $n^{\circ} 81$

Antunes WC, Pompelli MF, Carretero DM, DaMatta FM (2008) Allometric models for non-destructive leaf area estimation in coffee (Coffea arabica and Coffea canephora). Ann Appl Biol 153:33-40

Balandier P, Lacointe A, Le Roux X, Sinoquet H, Cruiziat P et al (2000) SIMWAL: a structural-functional model simulating single walnut tree growth in response to climate and pruning. Ann For Sci 57:571-585

Bell A (1991) Plant form: an illustrated guide to flowering plant morphology. Oxford University Press, London

Borianne P, Brunel G (2012) Automated valuation of leaves area for large-scale analysis needing data coupling or petioles deletion. In: Guo Y, Kang MZ, Dumont Y (eds) Plant growth modeling, simulation, visualization and applications. Proceedings PMA12: the fourth international symposium on plant growth modeling, simulation, visualization and applications, Shanghai, China, 31 October to 3 November 2012. IEEE Press, Beijing, pp 50-57

Bosc A (2000) EMILION, a tree functional-structural model: presentation and first application to the analysis of branch carbon balance. Ann For Sci 57:555-569

Cilas C, Bar-Hen A, Montagnon C, Godin C (2006) Definition of architectural ideotypes for good yield capacity in Coffea canephora. Ann Bot 97:405-411 
DaMatta FM, Ronchi CP, Maestri M, Barros RS (2007) Ecophysiology of coffee growth and production. Braz J Plant Physiol 19(4):485-510

Davis AP, Govaerts R, Bridson DM, Stoffelen P (2006) An annotated taxonomic conspectus of the genus Coffea (Rubiaceae). Bot J Linn Soc 152:465-512

Davis AP, Tosh J, Ruch N, Fay M (2011) Growing coffee: Psilanthus (Rubiaceae) subsumed on the basis of molecular and morphological data; implications for the size, morphology, distribution and evolutionary history of Coffea. Bot J Linn Soc 167:357-377

de Reffye P, Hu B (2003) Relevant choices in botany and mathematics for building efficient dynamic plant growth models: the GreenLab case. In: Hu B, Jaeger M (eds) Plant growth models and applications. Tsinghua University Press, Springer, Beijing, pp 87-107

Diao J, De Reffye P, Lei X, Guo H, Letort V (2012) Simulation of the topological development of young eucalyptus using a stochastic model and sampling measurement strategy. Comput Electr Agric 80:105-114

Dias PC, Araujo WL, Moraes GABK, Barros RS, DaMatta FM (2007) Morphological and physiological responses of two coffee progenies to soil water availability. J Plant Physiol 164:1639-1647

Godin C, Caraglio Y (1998) A multiscale model of plant topologic structures. J Theo Biol 191:1-46

Griffon S, de Coligny F (2014) AMAPstudio: an editing and simulation software suite for plants architecture modelling. Ecol Model. doi:10.1016/j.ecolmodel.2013.10.037

Hallé F, Oldeman RAA, Tomlinson PB (1978) Tropical trees and forests. Springer, Berlin

Leroy T, Montagnon C, Cilas C, Yapo A, Charmetant P, Eskes AB (1997) Reciprocal recurrent selection applied to Coffea canephora Pierre. III. Genetic gains and results of first cycle intergroup crosses. Euphytica 95:347-354

Leroy C, Saint-André L, Auclair D (2007) Practical methods for non-destructive measurement of tree leaf area. Agrofor Syst 71:99-108. doi:10.1007/s10457-007-9077-2

Lopez G, Favreau RR, Ssmith C, Costes E, Prusinkiewicz P (2008) Integrating simulation of architectural development and source-sink behavior of peach trees by incorporating
Markov chains and physiological organ function submodels into L-PEACH. Funct Plant Biol 35:761-771

Mathieu A, Cournède PH, Letort V, Barthelemy D, de Reffye P (2009) A dynamic model of plant growth with interactions between development and functional mechanisms to study plant structural plasticity related to trophic competition. Ann Bot 1-14. doi:10.1093/aob/mcp054

Montagnon C (2000). Optimisation des gains génétiques dans le schéma de sélection récurrente réciproque de Coffea canephora Pierre. PhD thesis, ENSA Montpellier, France

Niinemets Ü (2001) Global-scale climatic controls of leaf dry mass per area, density and thickness in trees and shrubs. Ecology 82:453-469

Perttunen J, Sievänen R, Nikinmaa E (1998) LIGNUM: a model combining the structure and the functioning of trees. Ecol Model 108:189-198

Rauscher HM, Isebrands JG, Host GE, Dickson RE, Dickmann DI (1990) ECOPHYS: an ecophysiological growth process model for juvenile poplar. Tree Physiol 7:255-281

Rosati A, Paoletti A, Caporali S, Enzo Perri E (2013) The role of tree architecture in super high density olive orchards. Sci Hort 161:24-29

Schmildt ED, do Amaral JAT, Santos JS, Schmildt O (2015) Allometric model for estimating leaf area varieties of Coffee. Rev Cie Agro 46(4):740-748

Siles P, Harmand JM, Vaast P (2010) Effects of Inga densiflora on the microclimate of coffee (Coffea Arabica L.) and overall biomass under optimal growing conditions in Costa Rica. Agroforest Syst 78:269-286

Tondjo K, Brancheriau L, Sabatier SA, Kokutse AD, Akossou A, Kokou K, Fourcaud T (2015) Non-destructive measurement of leaf area and dry biomass for estimating photosynthesis production in Tectona grandis. Trees. doi:10.1007/s00468-015-1227

Wang F, Letort V, Lu Q, Bai X, Guo Y, De Reffye P, Li B (2012) A functional and structural mongolian scots pine (Pinus sylvestris var. mongolica) model integrating architecture, biomass and effects of precipitation. PLOS One 7(8):1-13

Yan HP, Kang MZ, De Reffye P, Dingkuhm M (2004) A dynamic architectural plant model simulating resourcedependent growth. Ann Bot 93:591-602 